\title{
SENSTTIVITY OF LAND TO CLIMATE CHANGE AND SUSTAINABLE DEVELOPMENT IN THE SUBMEDITERRANEAN KARST AREA OF BOSNIA AND HERZEGOVINA
}

\author{
Hamid ČUSTOVİĆ ${ }^{1 *}$, Melisa LJUŠA ${ }^{1}$, Mirsad KURTOVIĆ ${ }^{1}$
}

UDK 631.4:551.583(497.6)

\begin{abstract}
The value of the landscape in the karst region of Bosnia and Herzegovina $(\mathrm{B} \& \mathrm{H})$ is the foundation of its existence and the key role in its appearance and formation is played by geomorphology and the soil. Through history the man has created a „cultural landscape” which is completely adapted to the natural conditions. He further enriches the space and makes it more appealing. Soils in B\&H karst are extremely heterogeneous and form a real pedological mosaic. Found on the Mesozoic sediments of limestone and dolomite of the Middle and Upper Jurassic and Early and Late Cretaceous are Bare rocks (barren land), Rocky grounds (Lithosol), Limestone-dolomite Black soil (Calcomelanosol) and Brown soil on limestone and dolomite (Calcocambisol). A specificity of these rocks are the screes that are transported down the hillside. A series may occur on them in which, if shale materials are contained, Rendzina appears as a calcareous soil. In addition to the above mentioned limestone and dolomite, there are marly limestones of Jurassic and Cretaceous age and Quaternary sediments on which Alluvial soils (Fluvisol) developed as well as the soils of karst fields which are sometimes very porous and skeletal and sometimes heavy and clayey on impermeable substrate (hydromorphic soils).

The paper will provide an overview of characteristic soil types in the Sub-Mediterranean upper and lower karst region of $\mathrm{B} \& \mathrm{H}$ taking into account a range of properties that make them sensitive and vulnerable within the ecosystem. These should include a lack of water on the surface and large fluctuations in the amount of water during the rainy and dry seasons and whimsicality of climate in general, which has a huge impact on the state of biodiversity and human lives in this region.
\end{abstract}

Keywords: karst, relief, soil types, climate change, aridity index

\footnotetext{
${ }^{1}$ Faculty of Agricultural and Food Sciences, University of Sarajevo, Zmaja od Bosne 8, 71000 Sarajevo, Bosnia and Herzegovina

*Corresponding author: custovic.hamid@gmail.com
} 


\section{INTRODUCTION}

Sub-Mediterranean Region of B\&H is characterized by a variable suite of surface landforms and subsurface features due to the dissolution of soluble rock such as limestone, gypsum or salt. Karst features include sinkholes, caves, springs, sinking streams, cavities, dissolution-enlarged joints and/or bedding planes, and cutter-pinnacle zones, not all of which may be present or obvious. The proper characterization of karst conditions is of vital importance for groundwater flow and structural stability models of a site. Its complexity and variation from site to site pose a significant challenge to site characterization efforts. In B\&H karst fields occupy about 100,000 ha.

Almost one half of the total territory of B\&H is accounted for by karst area (limestonecalcareous terrains). The main characteristics of that area are the processes of desertification, floods and soil erosion. Soil erosion and torrent processes were very high in the past and today. The uneven pluviometry regime, very steep slopes of relief, destructive human activities and historical precedent of tectonic intensity have been the main drivers of erosions and flood processes. Such processes have transformed the natural landscape into limestone gray desert, exposing the nude stones on the surface. Long ago these zones were known as "passive areas" (unproductive zones) and the term "karst" was a synonym for poverty (Aley, 1992). The karst fields have been only potentially fertile but effectively unfertile "oasis" in the surrounding karstic grayness.

The condition of ecological balance in the area of Mediterranean karst is complicated by the climate change phenomenon. This is best shown in the drought index analysis which indicates that the highest increase of the Index during the vegetation period occurred in the area of Mediterranean karst, i.e. Mostar. The increase was determined at the level of vegetation period, seasonal period as well as at monthly level. During the vegetation period the coefficient of increase averaged between 0.08 and 0.2 , and during the summertime between 0.02 and 0.20. Capriciousness of the climate and effects of drought on biodiversity of the area further complicate the karstic character of the area which developed mostly shallow skeletal soils, inclined relief affected by erosion and very porous geologic substrate which cannot retain water on the surface.

This area is severely affected by soil erosion and desertification (Čustović, 2007). The scarcity of soil functions in terms of agriculture and biodiversity, combined with a previous period of industrial development caused depopulation which became particularly apparent after the recent war. Now, in some karst areas population has been drastically reduced, in some places by more than $60 \%$ and in many areas by as much as $100 \%$ (parts of the municipalities of Glamoč, Bosansko Grahovo, Petrovac, Nevesinje, Gacko, etc.). This situation affects the condition of land as well as change in functions of soil in the ecosystem. Depopulation leads to the abandonment of traditional forms of agriculture which directly threatens the preservation of biological diversity and supports rapid succession (Marković, 2011). 
Soil formation process on karst terrain, with limestones and dolomites is very slow. In view of the importance of soil and its multi-functionality, this paper is aimed at analyzing the extent and nature of soil in this part of B\&H, vulnerability of shallow and skeletal soil exposed to the different types of erosion and anthropogenic pressures. Adaptation, adaptive capacity and vulnerability of soil to climate change in the SubMediterranean Region of $\mathrm{B} \& \mathrm{H}$ is the aim of this paper.

\section{MATERIAL AND METHODS}

Drought index for B\&H was obtained using the SPI method. To calculate the SPI index we analysed the 1961-2012 reference data series for various time scales and compared it with the area of Mediterranean karst, i.e. weather station Mostar.

Based on Aridity Index, i.e. P/PET ratio, the extent to which the evaporation is compensated by precipitation was calculated for each month and season as well as for annual average on the entire territory of B\&H. Determined were monthly, quarterly (June, July and August) and annual levels of the average index for the reference period 1961-1991, and the account was taken of data on precipitation and PET from 53 weather stations across B\&H.

Table 1. Classification of aridity/humidity

\begin{tabular}{lc}
\hline Zone & UNEP (1992) P/PET (Thornthwaite method) \\
\hline \hline Very arid & $<0.05$ \\
\hline Arid & $0.05-0.20$ \\
\hline Semi-arid & $0.20-0.50$ \\
Sub-humid & $0.59-0.65$ \\
Humid & $>0.65$ \\
\hline
\end{tabular}

The analysis of land cover/land use and their change was performed using the CORINE Land Cover methodology for B\&H.

To define the types of soil we used the Basic Soil Map M 1:50 000.

\section{RESULTS}

\section{Karst area}

Based on the relief forms, soil properties, land use, drought occurrence and the like, $\mathrm{B} \& \mathrm{H}$ can be divided in four agro-ecological areas: the area of high karst with karstic fields; the area of low Herzegovina (to include the upper course of the Neretva and 
karstic fields); the central hilly-mountainous area with river valleys, and; the plain hilly area (including serpentine and flysch zones) (Čustović et al., 2015).

In this paper, the focus is placed on the area of high karst with karstic fields and the area of low Herzegovina.

The area of high karst with karstic fields is a mountainous region situated at $800 \mathrm{~m}$ above sea level, which encompasses a significant number of high mountains extending in the Dinaric direction (NW-SE) and with pronounced relief forms and inclinations. Basic features of the Dinaric relief include deep river valleys and canyons, vast karstic fields and mountain ranges whose altitude goes from 1,000 to the highest peak of Maglić at 2,386 m (Čičić, 2002). Karstic fields (such as Bosansko Petrovačko, Glamočko, Livanjsko, Duvanjsko-Šuičko, Kupreško, Gatačko, Nevesinjsko) are enclosed karst valleys resembling green oasis in the karstic grey. Sloped terrain of the surrounding mountains is covered mostly by very shallow soils with pasture vegetation, shrubbery and degraded forests, which is exposed to strong erosion and denudation processes. Activities in the higher areas have a direct effect on the state of soil in karstic fields and ground waters.

The area of low Herzegovina (including the upper course of the river Neretva and karstic fields), in terms of geomorphology is known as low Mediterranean Herzegovina which encompasses the upper course of the river Neretva, the hinterland reaching Posušje, Stolac, Bileća and Livanjsko field which is the world largest karst field and is located at the transition zone towards the high karst. The entire area is criss-crossed by hillocks, hills and other relief forms at an altitude ranging between 500 and 700 ma.s.l. It accounts for about $10 \%$ of the total area of $\mathrm{B} \& \mathrm{H}$ and is surrounded by mountains such as Trtla, Viduša, Ivan, etc., and karstic fields on the upper terraces such as Mostarsko blato, Bekijsko polje, Kočerinsko, Dabarsko and many other smaller fields and plateaus. In the canyon of the river Neretva, represented are the sediment alluvial and colluvial-diluvial deposits in the Bijelo and Bišće fields, Hutovo Blato, as well as some smaller fields in the delta of the Neretva in Metković. In the very south of $\mathrm{B} \& \mathrm{H}$, in the valley of the Trebišnjica river there are Trebinjsko and Popovo fields. This area, just like the above mentioned one, is characterized by pronounced karstic erosion along with other karst phenomena. Fields are semienclosed or enclosed, and their hydrological regime is regulated by the capacity of sinking zones to receive surplus rainfall in the fall and winter period. Droughts are a frequent occurrence related to the growing season when the water is most needed by plants, which reflects negatively on agricultural production. On the other hand, there is the problem of flooding and long-term waterlogging from fall to spring, which further aggravates the situation. Agriculture is relatively intensive, especially along the rivers Trebišnjica and Neretva, where irrigation causes sporadic occurrence of secondary salinization. 


\section{Land cover/land use}

The area of high karst with karstic fields covers an area of 1,177,465 ha, and the area of low Herzegovina (including the upper course of the river Neretva and karstic fields) an area of 468,297 ha.

According to the CORINE 2012 data (Table 2), the most represented category of land cover/land use is the category of „Forest and semi natural areas" which accounts for $1,274,599.4$ ha or $77.4 \%$ of the entire observed territory. This category is predominant in both areas. In the area of high karst with karstic fields, this category covers $969,632.7$ ha or $82.3 \%$, and in the area of low Herzegovina $304,966.7$ ha or $65.1 \%$. The second most represented category is the category of „Agricultural areas“" which accounts for an area of 338,927.2 ha (20.6\%) of the total observed area, of which $203,157.7$ ha $(17.3 \%)$ in the area of high karst, and $135,769.5$ ha $(29 \%)$ in the area of low Herzegovina. In the area of both zones, the artificial surface category covers $12,928.1$ ha $(0.8 \%)$, Wetlands $4,293.5$ ha $(0.3 \%)$ and Water bodies $15,013.8$ ha $(0.9 \%)$.

Table 2. Land cover/use in the karst area of B\&H

\begin{tabular}{ccc}
\hline CLC category & Surface (ha) & \% \\
\hline \hline 1 Artificial surfaces & $12,928.1$ & 0.8 \\
\hline 2 Agricultural areas & $338,927.2$ & 20.6 \\
\hline 3 Forest and semi natural areas & $1,274,599.4$ & 77.4 \\
\hline 4 Wetlands & $4,293.5$ & 0.3 \\
\hline 5 Water bodies & $15,013.8$ & 0.9 \\
\hline Total & $1,645,762.0$ & 100.0 \\
\hline
\end{tabular}

Total changes in land cover/land use in the karst area (high karst and low Herzegovina) in the period 2000-2012 amount to $23,595.23 \mathrm{ha}$, with $82.6 \%$ of changes recorded in the period 2000-2006. The biggest changes were identified in the forest vegetation amounting to $17,967.58$ ha which is $76 \%$ of the totally identified changes in land cover/land use in karst areas. When it comes to agricultural land, total changes in this category amount to $5,168.10$ ha or $21.9 \%$ of the identified changes.

Pronounced depopulation of the karst area is a consequence of the extreme depopulation politics in the past as well as the fact that during the war it was mostly occupied and sustained extreme demographic changes (Marković, 2011). Analysis of data from the 1991 Census as well as preliminary data of the 2013 Census shows that the population in rural areas has been drastically reduced, e.g. Glamoč municipality where the population was reduced by as much as $68 \%$ or the municipality of Bosansko Grahovo 
whose population was reduced by $63 \%$. Such trends are also characteristic for other rural areas of the region.

„The landscape surrounding the karst fields above $500 \mathrm{~m}$ altitude were traditionally linked to extensive livestock production, mainly sheep and goats, less cattle. However, due to depopulation, lack of fresh water for households and animals, lack of appropriate agricultural machinery and improvement of pastures, lack of civilization events in these areas, the number of livestock was dramatically reduced and the area almost deserted“" (Čustović, 2007).

The phenomenon of poverty in this region is not just a simple lack of income to purchase the basket of basic goods. Poverty is a form of insecurity and exposure to uncertainty. It consists of increasingly present phenomenon of climate change, the inability to access elementary needs such as adequate good, drinking water and sanitary services, education and health care, employment and entrepreneurial opportunities. In a nutshell, this is a condition where basic opportunities for a dignified life are lacking.

\section{Climate changes}

The Sub-Mediterranean region is also affected by climate changes. Drought index by the SPI method was applied for the Mostar station (Figure 1). The Standardized precipitation index $\left(\mathrm{SPI}_{12}\right)$ in the weather station Mostar displays a negative linear trend, which indicates the occurrence of a drought increase. The coefficient of determination R2 equals 0.055 and this is the biggest negative trend in $\mathrm{B} \& \mathrm{H}$. The main disadvantage of this method is that it can observe changes only in precipitation patterns of a specific region.

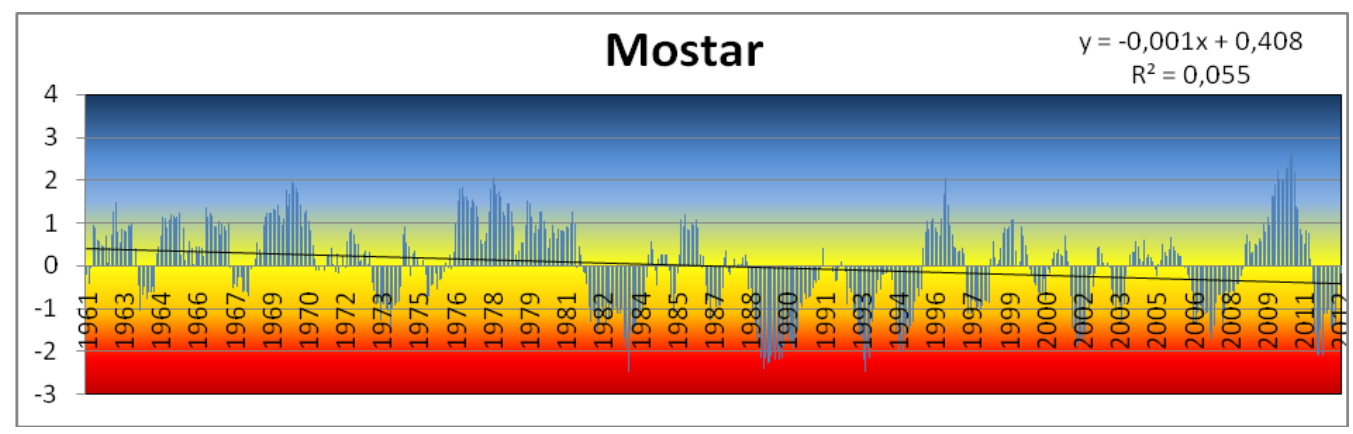

Chart 1. SPI 12 in the area of Mostar $(1961-2012)$

Different aridity indices are applied to perceive drought from several aspects such as the Aridity index based on P/PET ratio presented below. 


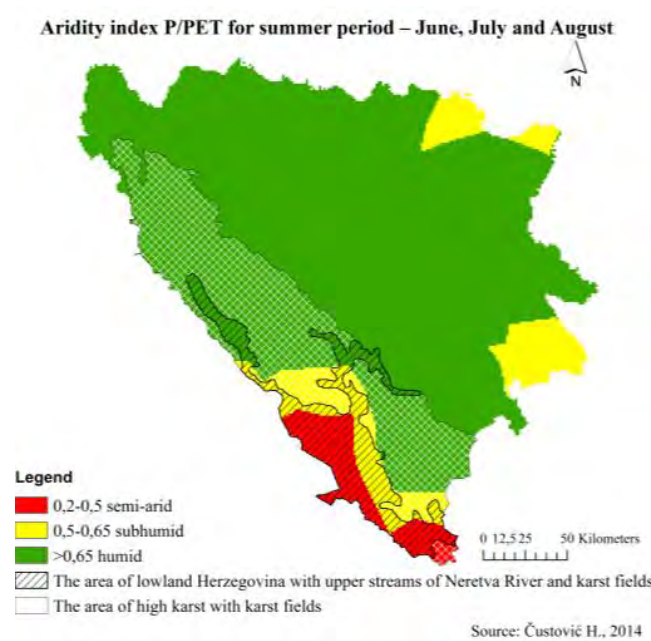

Figure 2. Aridity index P/PET for summer period - June, July and August

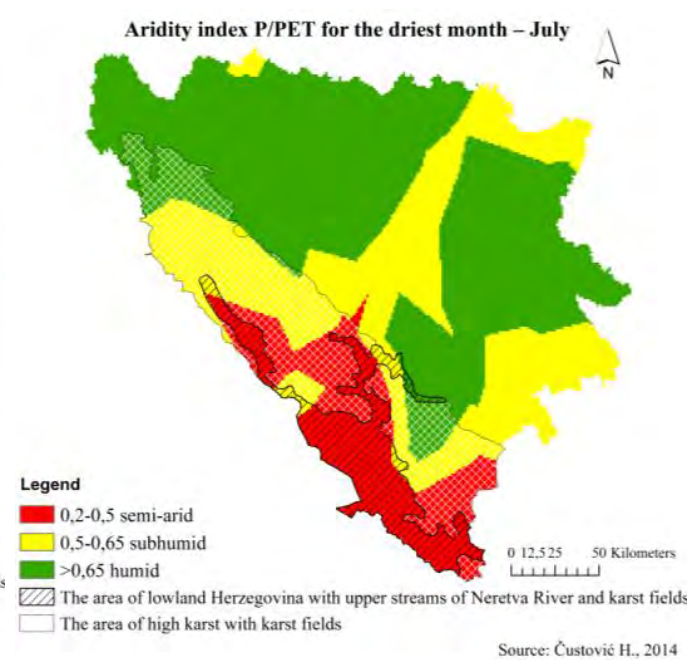

Figure 3. Aridity index P/PET for the driest month - July

As shown on the map of average values for summer period (June, July and August) within the period 1961-1991, semi-arid zones in our conditions represent the most vulnerable areas to drought and water deficit. They are typical of the southernmost part of the country, namely the area of the southern Sub-Mediterranean part of B\&H. Summer period is driest in the area of Herzegovina where average Aridity index amounts 0.50 . In the area of Herzegovina, on a monthly level, the Aridity index is lowest in July and August, when it varies from 0.26-0.63 (semi-arid to semi-humid). Also, a comparative analysis of multiyear series of data was made for the periods 1961-1991 and 2000-2012. A comparison of the two series indicates an increase in the Aridity Index level or precipitation deficit, which is particularly acute during the growing season. The increase in the Aridity Index that is present at all the shown meteorological stations or locations, was determined at vegetative, seasonal and monthly levels. During the growing season this increase ranged from 0.08 to 0.2 , and during the summer from 0.02 to 0.25 . The largest increase in the growing season was established for the area of Mostar (the difference between the periods amounted to 0.2 ).

It is necessary to point out that mean values for a longer period of time are used to develop Aridity index, so the extremes and high oscillations are not observed by this method. Finally, we need to say that the foreseen changes in precipitation and its distribution patterns (spatially and seasonally), combined with a rise in temperature and evaporation, resulting in increased precipitation deficit, will likely continue to cause extreme events 
(drought) and lead to the lack of access to water during summer when most needed by plants. The area of Herzegovina particularly stands out (most severely in lime and karst areas) as these changes are most pronounced there. As a consequence of the aforementioned, we are going to have decreased yields in the future due to reduced precipitation, increased evaporation and decreased soil moisture supplies.

\section{Soil characteristics}

The formation of soils is primarily affected by physical and geographical factors, first and foremost by geological structure, relief, climate, vegetation and especially water. Their impact leads to decomposition of the surface layer of rocks and minerals on which different soil types are formed. Each soil type at a specific site brings special features into the vegetation cover of natural vegetation, and if used in agriculture, into the possibility of growing various crops of special quality. As shown on the map provided below (Figure 4), there are six major types of soil in the researched area. In terms of production as well as the environment, these are the most important but also the most vulnerable types of soil of this ecosystem. Provided below is a description of soil types and their major characteristics within the ecosystem.

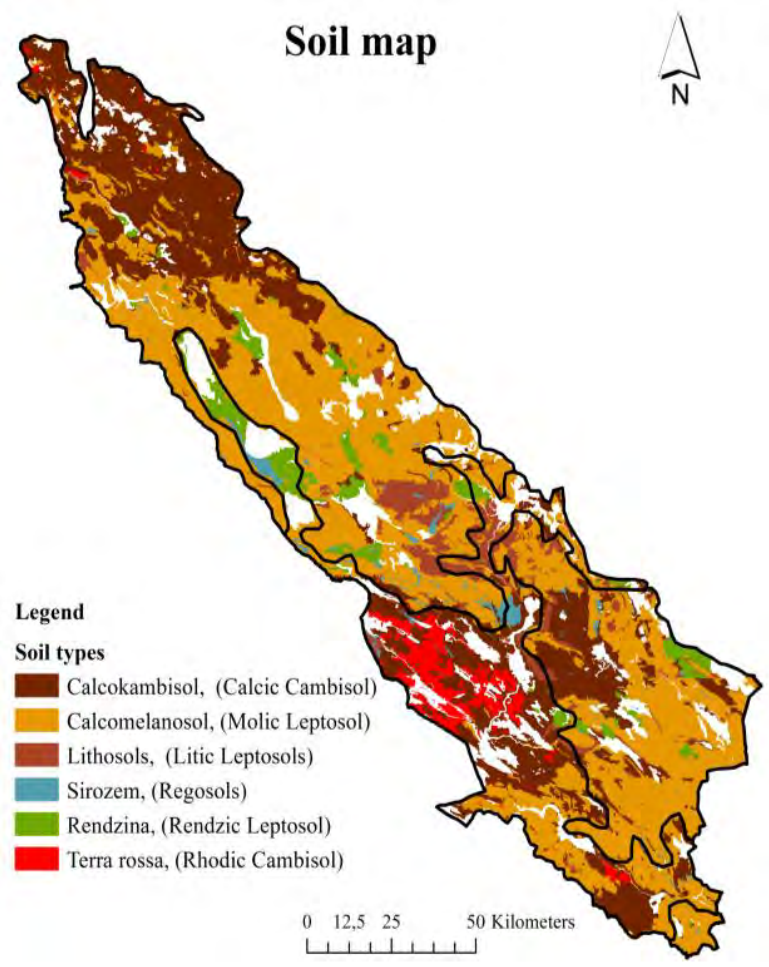

Figure 4. Soil map 


\section{Lithosols, (Litic Leptosols)}

In this area, Lithosols developed on limestone and dolomite. So, these are the bare rocks or areas where rockiness level goes up to $90 \%$. As these are extremely dry habitats, their scarce vegetation is mainly xerothermic. The total area of these soils amounts to $89,533.6$ ha or $5.4 \%$ of the total observed karst area. Although these soils are important in terms of biodiversity, one must not lose sight of the fact that Lithosol is a result of destructive processes in the pedosphere. Effective protection of this soil through growing natural vegetation cover and allowing pedogenesis to progress to a stage which enables growth and maintenance of the grass or forest vegetation cover should be a permanent goal. The stabilization and linkage of creeps or screes is of special environmental importance. This is the preferred direction of management. Protection against erosion by water and wind should certainly be envisaged as a required measure. On the pastures this role could be played by dry stone walls. When it comes to natural vegetation, the most common is the community of Coridaletumliospermae (Fukarek, P., 1962). It should be noted that overgrazing on Lithosol opens the way to the destructive processes, but plant roots strongly hold on to the soil protecting it from erosion. Additionally, the hooves of sheep or goats can „,cut into “the soil thus opening the way to erosion as well as some other human activities such as excavation. Figures 5. and 6. are the best examples of the mosaic pattern of soil cover even in a very small area, caused by topography - Rocky ground (Lithosol) alternates with limestone dolomite black soil (Calcomelanosol) in a mosaic pattern. Such a sequence of soils is called toposequence as the (micro- and meso-) topography determines the structure of the soil cover, i.e. the ,achievements "of soil formation.
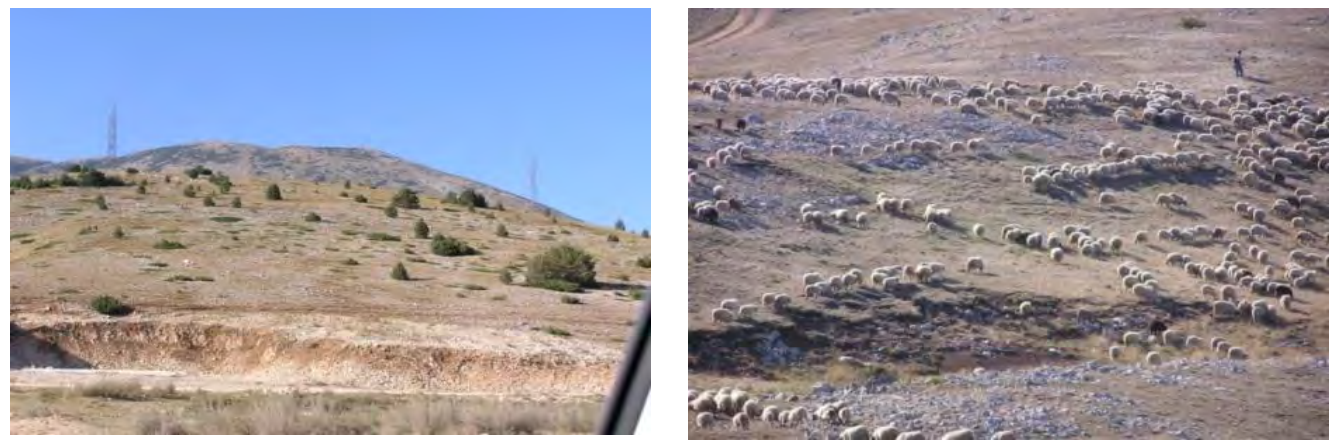

Figure 5 and $6 . \quad$ Lithosol is a substrate for poor pastures with xerothermic species resistant to drought as predominant (Bašić, F., 2012) 


\section{Sierozem, (Regosols)}

Regosols are undeveloped or poorly developed soils on loose substrates which are generally not skeletal. They are formed by erosion of previously formed soils and initial processes of pedogenesis which have not yet resulted in the formation of humus A horizon due to its young age, erosion or human impact. Depending on the relief situation and geological substrate they occur in association with Lithosols and Calcomelanosols. These initial soils are rather important in crop production as the biologically active zone, represented by undeveloped Ai initial horizon, is deepened by loose $\mathrm{C}$ horizon which is also environmentally suitable for higher plants as it is porous, retains water and has enough air thus enabling rooting of plants. The most suitable for crop production are carbonate-silicate Regosols, especially its variants formed on marl. These soils occupy the foot of the slope and more stable positions in relation to Lithosols. Such topographic position at the foot of the mountains allows for soil to remain in the initial stages of development. These are most commonly the areas of pasture and forest association. Forest species particularly favour Regosols as the substrates of these soils are soft so the penetration of roots is without difficulties and they also retain water well. Pastures are somewhat more suitable than those on Lithosols. When it comes to the guidelines for the management of these soils, they should involve actions similar to those for Lithosols. Regosols are poor in humus, phosphorus and potassium so they respond well to the application of manure and mineral fertilizers. If used in agriculture, Regosol is particularly suitable for the cultivation of root crops where a high quality of products can be achieved. In the Sub-Mediterranean and Mediterranean zone these are the soils on which grapes and olives are successfully grown. Erosion control is the only way for ensuring evolution of these soils; Lithosol will evolve into Calcomelanosol and ultimately to Calcocambisol, while Regosol will gradually evolve into Rendzina. Total area of these soils amounts to $21,832.3$ ha or $1.3 \%$ of the total observed area.

\section{Calcomelanosol, (Molic Leptosol)}

This type of soil belongs to the class of calcaric humus-accumulative soils with A-R and A-C structure of profile. It is formed on hard limestones and dolomites, on reliefs prone to erosion. The presence of limestone and dolomite parent substrate, pronounced relief and high altitude have a decisive influence on the development of this type of soil. Soil reaction mostly ranges within limits, $\mathrm{pH}$ slightly acid to alkaline. These limestonedolomite black soils have a rather high content of humus. In terms of textural composition they are mostly loamy loose sandy soils and sandy clays. Thus, it can be stated that these are light soils with favourable properties when it comes to the rooting of plants. The total porosity (pore volume) exceeds $50 \%$, and the level of water capacity is also high (over 50\%), which implies that these soils are porous but also with a large absolute water capacity thanks to the high percentage of organic matter and humus. From the aspect of physical and chemical properties, limestone-dolomite black soils could be characterized as favourable soils provided there are no other limiting factors 
(shallow profile, rockiness and stoniness, etc.) causing their unsuitability for any intensive crop production; therefore, they are mainly used as pastures, while colluvial deposits of black soil in depressions are used for growing potato. The total area of these soils amounts to $752,695.9$ ha or $45.7 \%$ of the total observed area.

\section{Rendzina, (Rendzic Leptosol)}

This is a humus-accumulative type of soil. It is developed on loose carbonate substrates (on loess, loess-like sediments, fluvioglacial sediments, soft limestones with a lot of silicate component, lake sediments, etc.). The parent substrate has a significant impact on pedogenesis. First and foremost, these are the substrates consisting of already fragmented clastic sediments or are quite easily physically weathered so that the process of pedogenesis takes place at a deeper carbonate regolith. Rendzina has a mollic, humusaccumulative horizon which is formed on loose carbonate substrate (IC). Usually a transitional AC horizon can be distinguished, so the profile structure is Ah-IC. Parent substrate has a high content of carbonates (over 20\%), and the whole profile is carbonate except for the variety of leached and brownised Rendzina. It most often occurs in association with Regosols which are formed from Rendzinas after they have been affected by erosion. The vegetation on these soils is considerably different from the surrounding one as it has a larger share of calciphile and xerothermic species, and erosion ,reveals "its hot spots if the vegetation has failed to cover the area and protect the soil. Rendzina is a very fertile soil with exceptionally favourable physical and chemical properties which requires abundant application of organic fertilizers for the successful production. They also require protection from erosion and permanent vegetation cover. The total area of these soils amounts to $68,089.5$ ha or $4.1 \%$ of the total observed area.

\section{Calcocambisol, (Calcic Cambisol)}

These soils of Dinaric karst, usually situated at an altitude ranging from 500 to $1200 \mathrm{~m}$ above sea level, account for 461,520 ha or $28 \%$ of the total observed area. They belong to the class of cambic soils, on calcaric/dolomitic substrates with mollic Amo or ochric Aoh humus horizon, which lies directly on cambic Brz horizon of characteristic brown colour. The process of soil formation takes place in situ on unaltered natural substrate. Morphological structure of the profile is $A h-B_{r z}-C n$. This cambic horizon is of somewhat heavier textural composition, more pronounced structure and significantly less humic compared to the surface horizon. Since limestone weathers very slowly, formation of soil on these substrates is slower, thus the higher risk of erosion. Depth of the solum varies, however, these are mainly shallow to medium deep soils. Soil reaction in the surface horizon ranges from slightly acid to neutral and slightly alkaline. They are rather humus rich soils in the first horizon, but the content of humus rapidly decreases with soil depth. By its texture the surface horizon generally belongs to loams. The entire 
depth of the soil is mainly non-carbonate or slightly carbonate. According to the physical and chemical properties these soils are good for various types of production, however, due to the often occurrence of surface rockiness and stoniness, the shallowness of the soil and the altitude at which they are formed (short vegetation period), they are not always suitable for intensive crop production. Therefore, they are mostly used as meadows and pastures, i.e. under the vegetation that is already adapted to the specific environmental conditions. These soils are characteristic for the processes which increase demineralization of humus and the accumulation of mineral component in residual horizon. They are as favourable as garden and arable soils. Arable land and gardens used to be the dominant type of land use, their size was much bigger with only rare meadows and pastures. Today, it is the other way around: arable land and gardens are rare and meadows and pastures are predominant though insufficiently used due to depopulation. Dry stone walls remain as a kind of landmark from the past, Figure 7. These soils are most threatened by wind or water erosion so that all measures to protect forest and agricultural soils are welcome. It is very risky to expose plowed soil on the slopes to the impact of rainfall, so the vegetation cover should therefore be preserved and maintained.

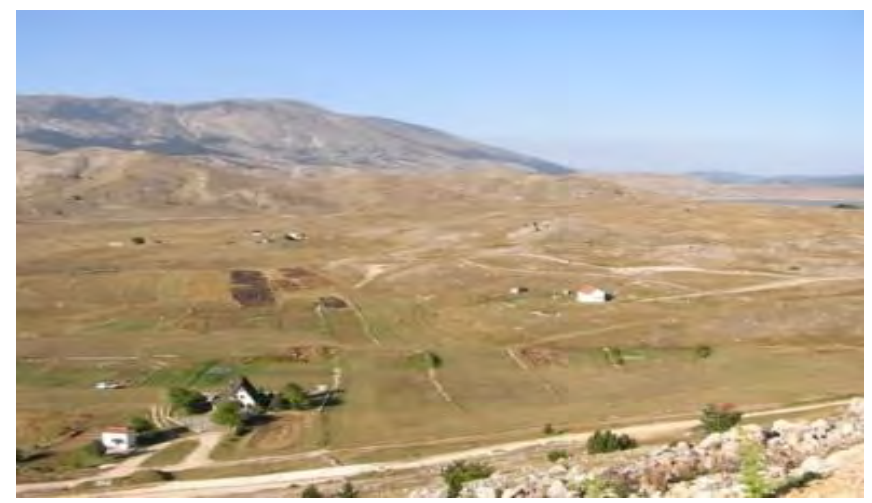

Figure 7. Dry stone walls (on the left) remain silent witnesses of past times, and the new buildings of what awaits us (on the right) (Bašić, F., 2012)

\section{Terra rossa, (Rhodic Cambisol)}

In $\mathrm{B} \& \mathrm{H}$, red soils are widespread on hard Mesozoic karstified limestone and dolomites in the Mediterranean karst area on flat positions and depressions rising to a maximum of $500 \mathrm{~m}$ above sea level. These are typical climatozonal soils of Ah-Brz-C type of profile. The main limitation of these soils is their depth and rockiness. The depth is determined by internal lithological structure and stratification of limestone as well as the inclination. These are also the most important limiting factors in agricultural 
production. Large areas in the low area of Herzegovina karst are covered by shallow red soils, spottily scattered and intersected by highly rocky areas which further complicates their use and protection. The red soils are rather similar to calcocambisols for their environmental and production properties. The total area of red soils amounts to 49,110.2 ha or $3 \%$ of the total observed area. Although the red soil is mostly clay soil, this property is corrected by good structure and favourable water-air regime. Neutral to slightly acid reaction is a very suitable property for growing the widest range of crops. However, this is the best soil for growing grapes and Herzegovina type of tobacco. It responds positively to fertilization with the most important macro-elements, especially nitrogen and phosphorus. Red soil in larger homogeneous areas can be moderately favourable for production, but in highly rocky and steep areas production is limited to small terraces built by human hands and protected from water and wind erosion by dry stone walls. These areas used to be covered by forest which is now destroyed either naturally or anthropogenically. Because of this, they are in many places eroded or completely destroyed (bare karst on the surface) with spots of red soils. Anthropogenic red soils are mainly related to terraced positions and sinkholes. Another significant problem is the deep karst erosion being the worst form of erosion. Thus, limitations in red soils, just like in calcocambisols, are determined by rockiness, the situation in relief, surface rockiness and depth of the soil. The red soils are also subject to the processes leading to an increased depth of mineral component and decreased humus content due to intensive mineralization.

\section{CONCLUSIONS}

The process of pedogenesis in the karst area of the Mediterranean region or mountain heights is characterized by dissolution of the Mesozoic limestones and dolomites, calcium and magnesium carbonates containing 0,1 up to maximum $5 \%$ of the so-called insoluble residue.

Another important process in the formation of soil pertains to the formation and transformation of organic matter, i.e. the process of humification. The content of humus in the soil depends on the intensity of two opposite microbiological processes: formation or humification and decomposition (mineralization) which results in the release of all biogenic elements embedded in the biomass from which humus is formed. In the researched area there are two „breaks "in the microbiological activity - the winter one due to low temperatures and the summer one due to drought, so that the processes at higher altitudes result in the predominant accumulation of organic matter, whereas at lower positions the process of accumulation and mineralization is balanced. For this reason, humus-accumulative soils such as Calcomelanosol and Rendzinas are prevalent in the pedosphere of high karst, and Calcocambisols and Red Soils in the pedosphere of low karst. Rocky grounds (Lithosols), Regosols (Sierozem) occur throughout the area in very steep relief positions, particularly on the southern and south-western exposures. 
Almost all Mediterranean countries have enough rainfall at the annual level to cover evapotranspiration needs. Similar situation is in B\&H and the Sub-Mediterranean region as well. But the distribution of rainfall during the year is very uneven in terms of space and time and is not in harmony with evapotranspiration distribution. The soil-water imbalance is the main limitation in agricultural production. Climate change has a very strong influence on all aspects of the ecosystem functions, particularly on the soil during the dry period of the year. During the cold part of the year there is too much rainfall when the evapotranspiration needs are very low. On the contrary, during the warm part of the year there is not enough rainfall and drought is often very acute.

In such conditions, farmers in rain-fed agriculture must be timely and accurately informed about the rainfall and soil water regime. In this way they can choose crops suitable for the specific rainfall distribution or make a better planning and production orientation. This could improve the protection of soil as one of the most important natural resources for humans.

The aim and task of comprehensive protection of the soil is to continuously maintain its main roles in a way that preserves natural ecosystems, all plant species and natural forests, makes the agro-ecosystem stable, ensures that agricultural production is at an acceptable level, without jeopardizing in any way the natural ecosystem - water, air and biological resources - flora and fauna. Agricultural production along with natural biodiversity and abundance of medicinal herbs, livestock and wild animals, should provide an aesthetically acceptable landscape, appealing to modern man. Soil protection is therefore a conditio sine qua non of the foundation, survival and improvement of this area. This effort requires activities on making an inventory of the condition of soils and establishing a continuous monitoring and appropriate information system.

Type of land use is an important issue not only for the establishment, but also for a sustainable survival and protection of the environment. In once different social and economic conditions of this area, the land that used to be cultivated is now abandoned and more or less left to nature - spontaneous vegetation..., and even in the parts that are still in use, the predominant type of use is again close to nature, namely grassland mountain pastures and meadows. Livestock production is focused solely on natural sources of fodder as it is not cultivated. The possibility of growing vegetables and medicinal herbs of exceptional quality has not yet been recognized due to potentially small yields. The conversion of this land to organic farming is one of the options for sustainable management of this area. For this reason, sustainable agriculture, with special emphasis on animal husbandry combined with sustainable management of grasslands - meadows and pastures, as well as the cultivation of vegetables, represents a realistic direction of development.

In order to stop further degradation of all components of the environment, i.e. soil, water, air, biodiversity, landscape, economic and historical heritage and to reverse the process towards improvement, it is necessary to: 
- support the economic viability of traditional farming systems and products and to contribute to the maintenance of landscape and biodiversity;

- foster regional management of natural and cultural resources to ensure longterm conservation of biodiversity (through important natural karst systems); and

- contribute to sustainable rural development by building a specific tourism product (brand).

\section{REFERENCES}

Aley, T. 1992. The Karst Environment and Rural Poverty. Ozarks Watch, Vol. V, No. 3 , pp. 19- 21. https://thelibrary.org/lochist/periodicals/ozarkswatch/ow50327.htm, Accessed: January 2015.

Bašić, F. 2012. Ekološka procjena početnog stanja Parka prirode Blidinje (studija Križevci, listopad 2012), p 20-30.

Čustović H. 2007. Basic soil characteristics of Bosnia and Herzegovina with the focus on Karst Mediterranean Region (status, issues and proposed solutions), Conference Proceedings ,Status of Mediterranean soil resources: Actions needed to support their sustainable use “, 26-31 May 2007, Tunis, Tunisia.

Čustović H., Ljuša M., Sitaula K.B., et al. 2015. Adaptation to climate change in agriculture. Faculty of Agricultural and Food Sciences, University of Sarajevo. $\mathrm{B} \& \mathrm{H}$.

Marković D. 2011. Dinarski krš-ugroze i načini zaštite, Proceedings of International Scientific Symposium „Man and Karst “, 13-16 October 2011, BijakovićiMeđugorje, BiH. 